\title{
A magyarországi regionális vasúti és autó- buszos személyszállítás párhuzamosságának analitikus vizsgálata logit-modell segítségével
}

Magyarország közlekedésében aktuális probléma a regionális autóbuszos és vasúti személyszállítás párhuzamossága, hiszen a fenntartható és hatékony közlekedés megköveteli, hogy az alágazatok - bizonyos határok között - egymás kiegészítői (komplementerei) legyenek. Hazánk összes régiójában megtalálhatjuk a párhuzamos autóbuszos és vasúti közösségi közlekedést, a mely a két alágazat közötti versenyhelyzetet eredményezheti, így nem teljesül a kiegészítő szerep. A probléma kezelésének érdekében szükséges a jelenlegi párhuzamos közösségi közlekedési lehetőségek optimalizálása.

DOI 10.24228/KTSZ.2019.5.3

\section{Lakatos András - dr. Mándoki Péter}

Budapesti Múszaki és Gazdaságtudományi Egyetem,

Közlekedésüzemi és Közlekedésgazdasági Tanszék

e-mail: lakatos.andras@mail.bme.hu, mandoki.peter@mail.bme.hu

\section{BEVEZETÉS}

Magyarország közösségi közlekedése meghatározó szerepet tölt be a mobilitási igények kielégítésében és nagyban befolyásolja a nemzetgazdaság alakulását is, ezért fejlesztése - többek között a meglévő párhuzamosságok optimalizálásával - elengedhetetlen. Ugyan az infrastrukturális innováció - a kormányzati és Európai Uniós forrásoknak köszönhetően - folyamatos (autópályák építése, vasúti pályák felújítása), azonban a makroszkópikus forgalomszervezési feladatok a háttérbe kerülnek. A hálózat teljes egészére vonatkozó szemléletmód is fontos részét képezi a fejlesztésnek, amelynek alkalmazásával az infrastrukturális beruházás op- timalizálható, valamint anyagi és emberi erőforrás takarítható meg az üzemeltetés során.

A párhuzamos közösségi közlekedés problémájára megoldást jelenthetne az állami támogatást mellőző, piaci alapú személyszállítási szolgáltatás, de az 1370/2007 EK rendelet kimondja, hogy „Jelenleg számos, általános gazdasági érdekü szükségletet kielégítő országos személyszállítási szolgáltatás nem müködtethető kereskedelmi alapon", ezért a közfinanszírozott, illetve piaci alapú szolgáltatás jelenléte dilemmákat vet fel [2].

Az alágazatok közötti munkamegosztással kapcsolatos kutatással foglalkozik a [4] és az [1], de vizsgálataikban csak a minden szem- 


\section{Közösségi közlekedés}

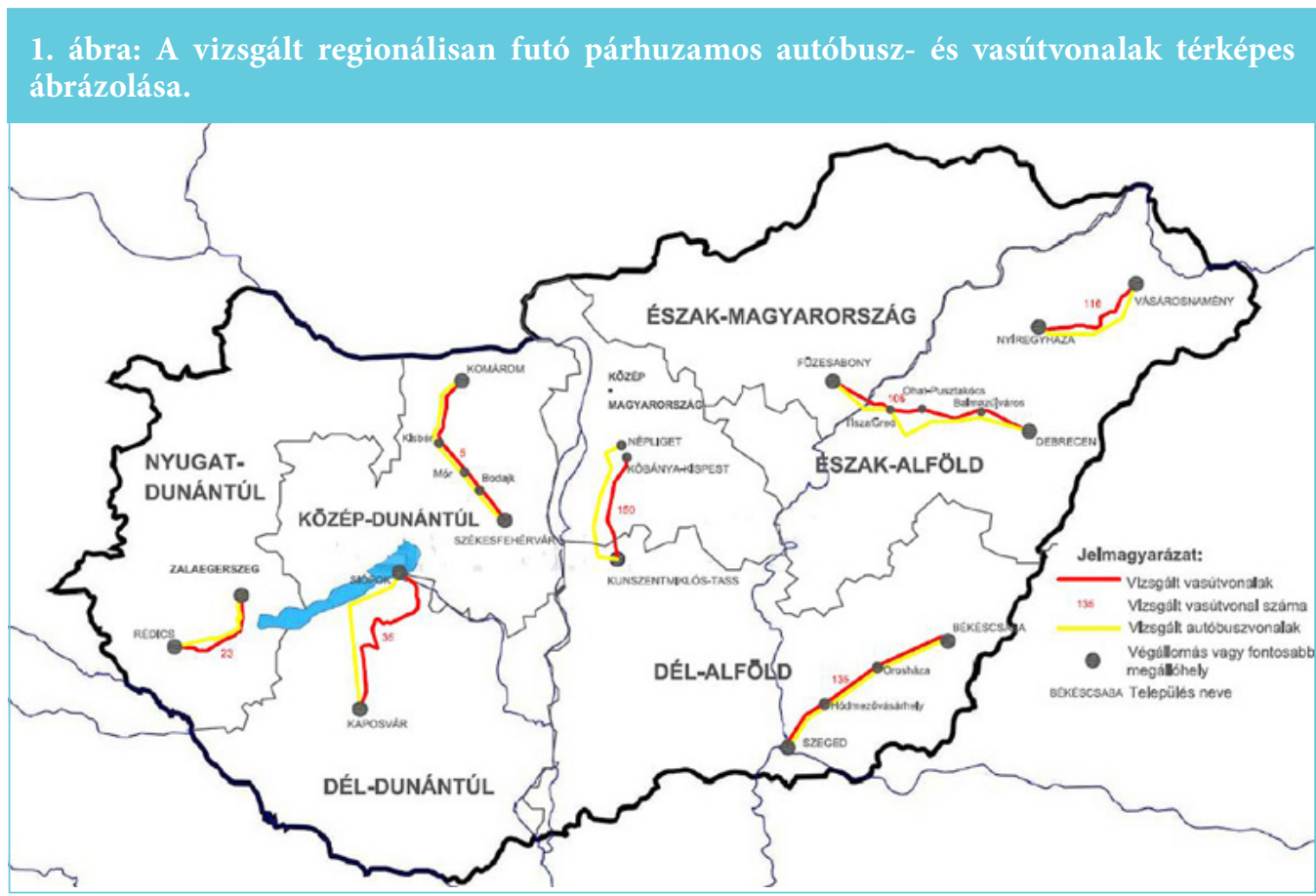

pontra kiterjedő, részletes elemzés elkészítéséről esik szó, azok módjáról, alkalmazhatóságáról, közlekedésszervezési lépéseiről azonban nem. A [3] már részletesebben foglalkozik a témával, amelyben hasonló, de más megközelítésén alapuló mutatószámot adnak meg. $\mathrm{Az}$ [5] a menedzsment oldaláról mutat be kutatási tevékenységeket.

A párhuzamos közösségi közlekedés terén végzett kutatás egyik részeként az érintett közigazgatási egységek mérete (például lakosszáma), valamint a menetrendekben meghirdetett kínálat, illetve a jármüvek (és utasok) hálózaton töltött időértékei alapján minőségimutató-értékeket - és ezzel együtt beavatkozási javaslatokat - definiáltunk az egyes, vizsgálat részét képező regionális és párhuzamos vonalakat illetően (1. ábra, 1. táblázat) [9].

Az említett adatok súlyozásával az 1. ábrán szereplő párhuzamos vonalakra kiszámítottuk a minőségimutató-értékeket, illetve határokat, valamint beavatkozási lehetőségeket határoztunk meg az egyes intervallumokhoz tartozóan, amelyet a 2 . ábra mutat.

\begin{tabular}{l|c|}
$\begin{array}{l}\text { 1. táblázat: Párhuzamos vonalakra vonat- } \\
\text { koztatott minóségimutató-értékek }\end{array}$ \\
\begin{tabular}{|l|c|}
\multicolumn{2}{|c|}{ Párhuzamos vonal megnevezése } \\
\hline Kaposvár - Siófok
\end{tabular} \\
\hline Székesfehérvár - Komárom & $-19,29$ \\
\hline Nyíregyháza - Vásárosnamény & $-13,71$ \\
\hline Zalaegerszeg - Rédics & $-1,68$ \\
\hline Szeged - Békéscsaba & $-5,00$ \\
\hline Budapest - Kunszentmiklós & $-0,29$ \\
\hline Debrecen - Füzesabohy & 2,03 \\
\hline
\end{tabular}

Jelen kutatás célja a 2. ábrában szereplő minőségimutató-értékhatárok validálása analitikus úton. A vizsgálat során a felhasználói eszközválasztást leíró - eljutási idő és eljutási költség alapú - súlytényezö-értékek kerülnek kiszámításra az 1. ábrán szereplő vonalak esetében a logisztikus regresszió, mint matematikai eszköz és a vonalakon végzett utasszámlálási adatok alapján. A módszer segítségével meghatározhatók az egyes súlytényezők függvényei a minőségi mutató felhasználásával. A függvények jellegét és szélsőértékeit vizsgálva pontosíthatók a 2. ábrán szereplő minőségi mutató intervallum-határok. 


\section{Közösségi közlekedés}

2. ábra: Beavatkozási javaslatok a minőségimutató-értékek függvényében.

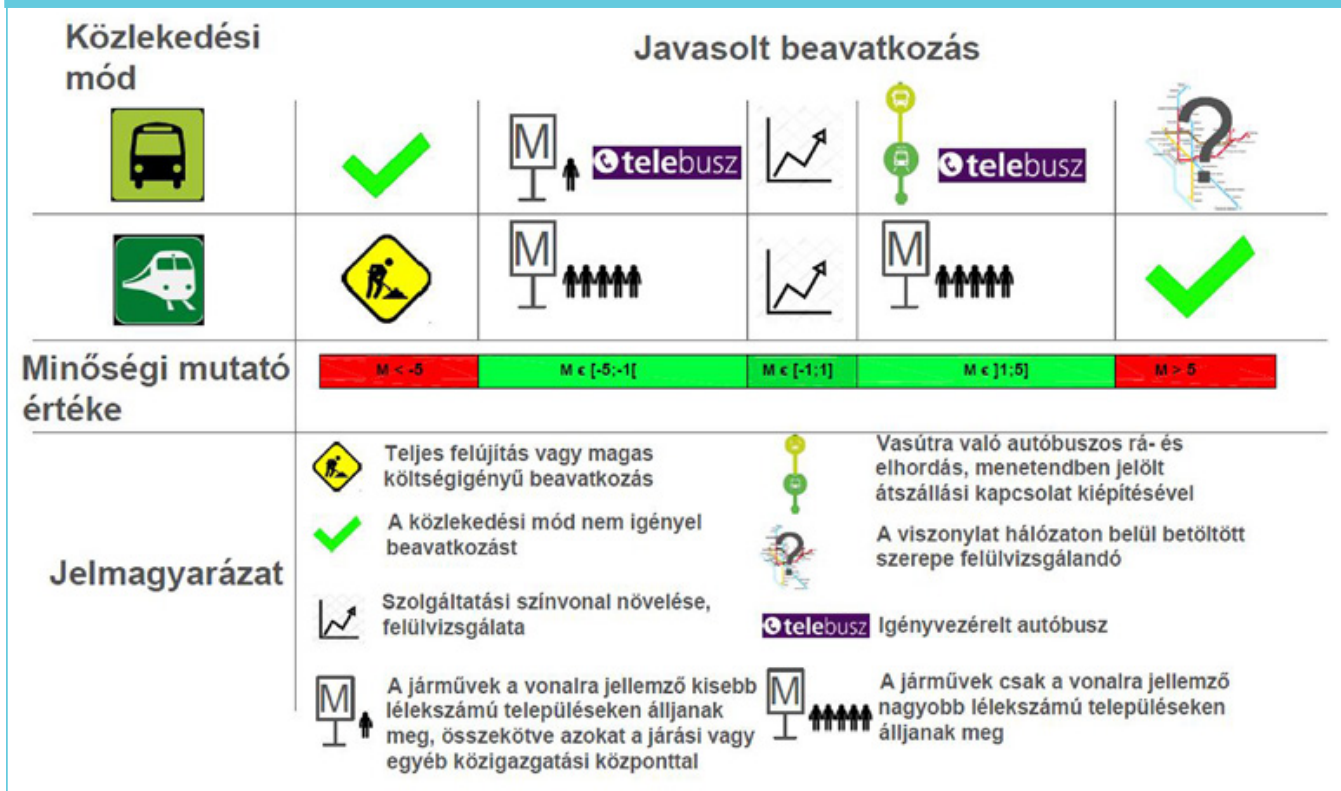

\section{A VIZSGÁLATI MÓDSZERTAN BEMUTATÁSA}

A helyváltoztatások eszközönkénti, térbeniidőbeni megoszlását az értékelhető tulajdonságok, azaz a meghatározott alternatíva léte és minősége determinálja. A közlekedési eszközválasztás a helyváltoztatások térbeni megoszlásának ismerete alapján valószínüségi modell segítségével írható le [7].

A logisztikus regressziós modell megfogalmazható egy valószínűségi modellként [6], [8] (1):

$\operatorname{logit}(\mathrm{y}=1)=\beta x$

Ahol y a diszkrét függő változó ( $\mathrm{y}=1 \mathrm{a}$ „siker”, $\mathrm{y}=0 \mathrm{a}$ „kudarc”), a logit függvény az argumentumban szereplö esemény esélyének logaritmusa, $\beta x$ pedig az együtthatók és a magyarázó változók lineáris kombinációja. A $\beta$ együtthatók a logisztikus regresszió paraméterei. A jobb oldalon ugyan nem szerepel hibatag, a megfigyelt kimenet és a magyarázó változók közötti kapcsolat sztochasztikus jellegére az utal, hogy a bal oldalon nem a megfigyelt kimenet, hanem a bekövetkezési esély logaritmusa szerepel.

A siker valószínűségét az alábbi módon lehet meghatározni (2):

$P(\mathrm{y}=1)=P(\alpha x+\sigma \varepsilon>0)=P(\varepsilon>-\alpha x / \sigma)=1-F(-\alpha x / \sigma)$

ahol:

- $\alpha x$ a magyarázó változók és az együtthatók lineáris kombinációja;

- $\varepsilon$ a logisztikus eloszlásfüggvény;

- $\sigma$ pedig a szórás.

A logisztikus eloszlásfüggvény szimmetrikus, a siker valószínűsége tehát (3):

$P(y=1)=F(\alpha x / \sigma)$

Mivel az (1) és (3) egyenletek ugyanazt a valószínűséget definiálják, a közvetlen valószínüségi modell $\beta$ együtthatói és a látens változós lineáris regressziós modell a együtthatói között a következő kapcsolat (4) áll fenn [12]:

$\beta=\alpha / \sigma$ 
Annakérdekében, hogy az egyes alternatívák (jelen esetben autóbusz vagy vonat) tulajdonságai súlyuknak megfelelően értékelhetök legyenek, egy lineáris kombinációjú, $g_{m}$ súlytényezőket figyelembe vevő hasznosság-függvényt, - amelynek általános alakját (5) adja meg - szükséges meghatározni minden alternatívához.

$$
U\left(x_{1}, x_{2}, \ldots, x_{n}\right)
$$

Mivel jelen esetben a vizsgálat tárgyát két közlekedési mód (autóbuszos és vasúti közlekedés) képezi, ezért a hasznosság-függvények a következőképpen alakulnak (6), (7):

$$
\begin{aligned}
& U_{b}=x_{11} \cdot g_{1}+x_{12} \cdot g_{2}+\ldots .+x_{1 m} \cdot g_{m} \\
& U_{v}=x_{21} \cdot g_{1}+x_{22} \cdot g_{2}+\ldots .+x_{2 m} \cdot g_{m}
\end{aligned}
$$

ahol:

- $X_{n m}$ : az m értékelhető tulajdonság az $n$ alternatívánál;

- $g_{m}$ : az adott tulajdonsághoz tartozó súlyszám;

- $U_{b}$ : az autóbusz-közlekedést leíró hasznosság-függvény;

- $U_{v}$ : a vasúti közlekedést leíró hasznosságfüggvény.

A forgalommegosztás során leggyakrabban alkalmazott tulajdonság a költség és az idő, amely a korábbi kutatások alapján a vizsgált hét regionális és párhuzamos vonal esetében rendelkezésre áll a városközponttól városközpontig tartó eljutások figyelembe vételével. Így a fenti egyenleteket átalakítva a következő hasznosság-fügvények állnak elő (8), (9):

$$
\begin{aligned}
& U_{b}=T_{b i, j} \cdot w_{t, b}+K_{b i, j} \cdot w_{c, b} \\
& U v=T_{v i, j} \cdot w_{t, v}+K_{v i, j} \cdot w_{c, v}
\end{aligned}
$$

ahol:

- $T_{b i, j}$ az autóbusz igénybevétele esetén az eljutási idő értéke $i$ és $j$ települések közötti relációban;

- $K_{b i, j}$ az autóbusz igénybevétele esetén az eljutási költség értéke $i$ és $j$ települések közötti relációban;

- $w_{t, b}$ az eljutási idő súlytényezője autóbusz-közlekedés esetén;
- $w_{c, b}$ az eljutási költség súlytényezője autóbusz-közlekedés esetén;

- $T_{v i, j}$ a vasút igénybevétele esetén az eljutási idő értéke $i$ és $j$ települések közötti relációban;

- $K_{v i, j}$ a vasút igénybevétele esetén az eljutási költség értéke $i$ és $j$ települések közötti relációban;

- $w_{t, v}$ az eljutási idő súlytényezője vasúti közlekedés esetén;

- $w_{c, v}$ az eljutási költség súlytényezője vasúti közlekedés esetén.

$\mathrm{Az} U_{b}$ és $U_{v}$ értékek függvényében az adott alternatíva $P_{b}$, illetve $P_{v}$ valószínűsége meghatározható az alábbi módon (10), (11):

$P_{b}=f\left(U_{b}, U_{v}\right)$

$P_{v}=f\left(U_{b}, U_{v}\right)$

A logit modellt alkalmazva a felírt bináris esetre (12), (13), (14):

$P_{n=1}=\frac{e^{U_{n=1}}}{\sum_{n=1}^{2} e^{U_{n}}}=\frac{e^{U_{1}}}{e^{U_{1}}+e^{U_{2}}}$

$P_{b}=\frac{e^{U_{b}}}{e^{U_{v}}+e^{U_{b}}}=$

$\frac{e^{T_{b i, j} \cdot w_{t, b}+K_{b i, j} \cdot w_{c, b}}}{e^{T_{v} i, j^{\cdot} w_{t, v}+K_{v i, j} \cdot w_{c, v}}+e^{T_{b i, j} w_{t, b}+K_{b i, j} \cdot w_{c, b}}}$

$P_{v}=\frac{e^{T_{v i, j} \cdot w_{t, v}+K_{v i, j} w_{c, v}}}{e^{T_{v i, j} \cdot w_{t, v}+K_{v i, j} w_{c, v}}+e^{T} b i, j^{\cdot w_{t, b}+K_{b i, j} w_{c, b}}}$

ahol: $0 \leq P_{n} \leq 1$ és $P_{b}+P_{v}=1$.

A hasznosság-függvények tényezői közül az eljutási költség-, illetve időértékek ismertek, viszont ismeretlenek ezen paraméterek súlytényezö-értékei $\left(w_{t, b}, w_{c, b}, w_{t, v}, w_{c, v}\right)$.

Ehhez a Közlekedéstudományi Intézet által 2016-ban végzett országos utasforgalmi felmérésből származó adatokat felhasználva elő- 
állíthatók relációnként a $\widehat{P_{b l, j}}$ és $\widehat{P_{v l, j}}$ megfigyelésen alapuló valószínüségi értékek az alábbi módon (15), (16):

$\overline{P_{b l, j}}=\frac{N_{b i, j}}{N_{\ddot{o} i, j}}$ és $\overline{P_{v l, j}}=\frac{N_{v i, j}}{N_{\ddot{o} i, j}}$

ahol:

- $N_{b i, j}$ az utasforgalmi felmérésből származó utasszámérték autóbusz esetén $i$ és $j$ relációban;

- $N_{v i, j}$ az utasforgalmi felmérésből származó utasszámérték autóbusz esetén $i$ és $j$ relációban;

- $N_{\ddot{o} i, j}=N_{b i, j}+N_{v i, j}$.

A hasznosság-függvényekben lévő súlytényezők (ismeretlenek) értékeinek meghatározása a logit-modell valószínűségi egyenleteinek és az utasforgalmi megfigyelésen alapuló valószínüségek $\left(\left(\widehat{P_{b l, j}}, \widehat{P_{v l, j}}\right)\right)$ hibaösszegének minimalizálásával történik a legkisebb négyzetek módszere segítségével (17), (18).

$$
\begin{aligned}
& \sum_{i, j}\left(\widehat{P_{b i, j}}-P_{b}\right)^{2} \rightarrow \text { Min. } \\
& \sum_{i, j}\left(\widehat{P_{v_{l, j}}}-P_{v}\right)^{2} \rightarrow \text { Min. }
\end{aligned}
$$

Részletesebben (19), (20):

Hibaösszeg $=$

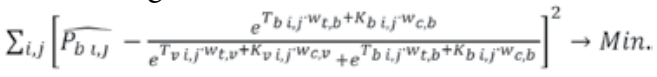

Hibaösszeg=

$\sum_{i, j}\left[P_{v i, j}-\frac{e^{T_{v i, j} w_{t, v}+K_{v i, j} w_{c, v}}}{e^{T_{v i, j} w_{t, j}+K_{v i, j} w_{c, v}}+e^{T_{b i, j} w_{t, b}+K_{b i, j} w_{c, b}}}\right]^{2} \rightarrow$ Min.
Az egyes relációkban vett súlyértékek minél pontosabb meghatározása érdekében a számítások az MS Solver programja segítségével készültek.

\section{A VIZSGÁLATI MÓDSZERTAN ALKALMAZÁSA}

A bemutatott vizsgálati eljárás alapján - az egyes, kutatásba bevont párhuzamos vonalak tekintetében külön-külön - meghatározhatók az eljutási időre és az eljutási költségre, mint súlytényezőkre vonatkozó számértékek. Mivel ezen értékek az összehasonlított párhuzamos, regionális autóbusz-, illetve vasútvonalakra értendők, ezért a súlytényezőkhöz hozzárendelhető az adott vonalra meghatározott minőségimutató-érték is (2. táblázat).

A 2. táblázatban foglalt eredményeket az idő-, valamint a költség szerinti megbontásban ábrázolva (3. ábra, 4. ábra) meghatározhatók az egyes minőségimutató-intervallumokban a kínálat alapján vett eljutásiidő- és eljutási költségértékek hatásai az eszközválasztásra. Fontos hangsúlyozni, hogy a beavatkozások az eljutási idő értékek minél magasabb súlyszámainak elérése érdekében határoztuk meg összhangban az eddig végzett gyakorlati kutatásokkal [9], [10]. Ugyanis a rövidebb távú (100 kilométer alatti) helyközi utazások során a válaszadók döntő többsége (közel 80\%-uk) az utazási időt jelölte meg az eszközválasztása során elsődleges preferenciaként.

A 3. és 4. ábrák alapján megállapítható, hogy -5 alatti minőségimutató-érték során az eljutási idő, mint súlytényező értéke kons-

\begin{tabular}{|c|c|c|c|c|c|c|c|c|}
\hline & $M[-]$ & $-19,29$ & $-13,71$ & -5 & $-1,68$ & $-0,29$ & 2,03 & 4,97 \\
\hline \multirow{2}{*}{ vonat } & $w_{t}[-]$ & 0,486 & 0,442 & 0,426 & 0,200 & 0,521 & 0,300 & 0,539 \\
\hline & $w_{c}[-]$ & 0,514 & 0,558 & 0,574 & 0,800 & 0,479 & 0,700 & 0,461 \\
\hline \multirow{2}{*}{ autóbusz } & $w_{t}[-]$ & 0,514 & 0,558 & 0,574 & 0,800 & 0,479 & 0,700 & 0,461 \\
\hline & $w_{c}[-]$ & 0,486 & 0,442 & 0,426 & 0,200 & 0,521 & 0,300 & 0,539 \\
\hline
\end{tabular}

2. táblázat: Súlytényező-értékek a minőségimutató-értékek függvényében. 


\section{Közösségi közlekedés}

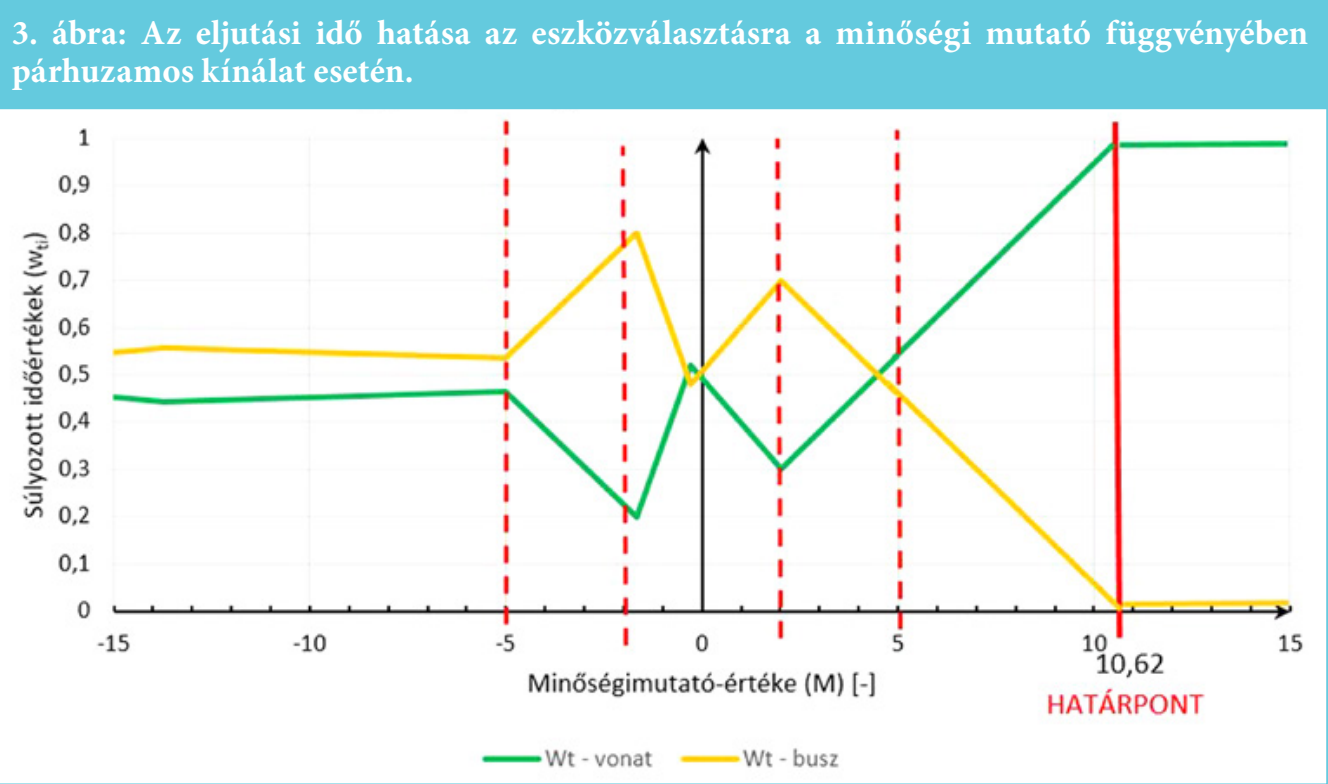

tans. Ugyan -15 minőségimutató-értéknél az egyenesek közötti távolság csökkenése figyelhető meg, de az eltérés mértéke alapján konstansnak tekinthető mindkét függvény. Megfigyelhető, hogy a felhasználók ilyen esetben 55\%-os súllyal a kedvezőbb eljutásiidő-értéket garantáló autóbusz-közlekedést választják, a vasúti közlekedést választók számára az eljutási költség jelenti a fö vonzerőt. Ezt jól magyarázzák az utasszámlálás során felvett adatok, ugyanis a jelzett intervallumban nagyságrendi (kb. 60-70-szeres) eltérések tapasztalhatók az autóbusz-közlekedés javára. Az e szakaszban tapasztalható konstans jelleg alátámasztja a beavatkozási javaslatokat, ugyanis az autóbusz képes kiszolgálni a kedvező eljutási idő miatt a hivatásforgalmat, míg a vasúti közlekedésben a nagyobb beruházás (pl. teljes vonalfelújítás, a nyomvonal újragondolása) jelentené a megoldást, amely tetemes költségigénye miatt meggondolandó. Az ebbe a kategóriába tartozó vasútvonalak (Kaposvár - Siófok, Székesfehérvár - Komárom, Zalaegerszeg - Rédics) közös jellemzője, hogy kis lakosszámú településeket szolgálnak ki, ahol a vasútállomás a helység közigazgatási határához közel helyezkedik el, továbbá a kínálati értékek is szimbolikusak. Ezzel szemben az autóbusz-közlekedés kedvező eljutásiidőértékeket garantál a település-központok feltárásával.

A -5 és -1 közötti intervallumot vizsgálva megállapítható, hogy a súlytényezők függvényei már - hozzávetőlegesen 45 fokos meredekségü - egyeneseket mutatnak, amelyek elöjelet váltanak -1,68 minőségimutató-értéknél. Ezért a korábbi kutatásokon alapuló intervallumhatár -1 értékről -2 értekre szükséges pontosítani. Az így kialakult -5 és -2 tartományban tehát megállapítható, hogy az autóbusz-közlekedést választók számára az eljutási idő, mint súlytényező eszközválasztásra gyakorolt hatása folyamatosan nő, míg a vasúti közlekedés eszközeit az utasok döntően annak költsége miatt veszik igénybe. A súlyszámok közötti legnagyobb különbség jelentős, kb. 0,6. Ezzel a vasúti közlekedés csak az eljutási költségek tekintetében marad versenyképes, amelyből kifolyólag javasolt a vasútvonalon található megállóhelyek optimalizálása a kedvezőbb eljutásiidő-értékek garantálása érdekében, ami a minőségimutató-érték növekedésével pozitív meredekségű $\mathrm{w}_{\mathrm{t}}$ egyenesre való illeszkedést eredményezheti, elősegítve a vasúti közlekedés - eljutási időbeni - versenyképességét. A kimaradó megállóhelyek kiszolgálását java- 


\section{Közösségi közlekedés}

4. ábra: Az eljutási költség hatása az eszközválasztásra a minőségi mutató függvényében párhuzamos kínálat esetén.

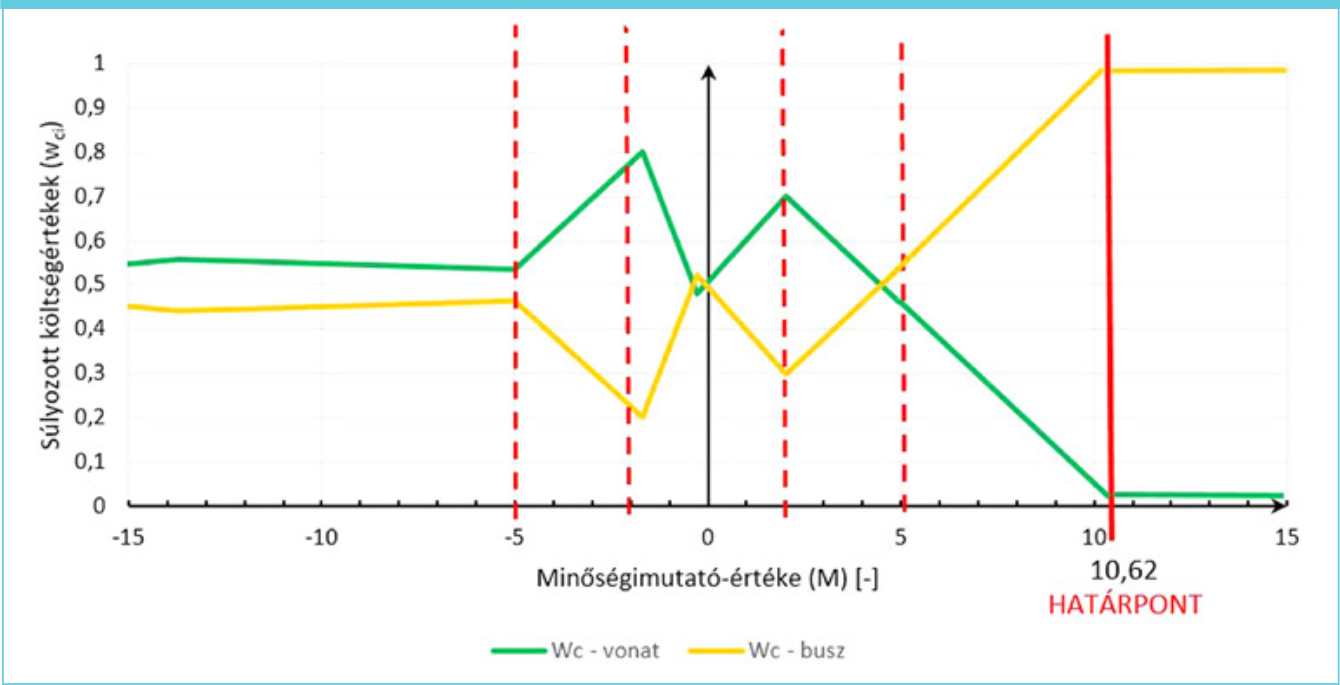

solt igényvezérelt autóbusz-közlekedéssel végezni. A megállóhely-optimalizálás versenyképességre gyakorolt hatásairól, hasznairól szól a [12], amit magyarországi viszonylatban a MÁV-HÉV Zrt., illetve külföldön a finn vasúttársaság is alkalmazott.

A -2 és 2 közötti intervallumot érdemes a grafikon alapján két részre osztani:

- -2 és 0 közötti szakasz;

- 0 és 2 közötti szakasz.

Az előbbi részen az autóbusz $\mathrm{w}_{\mathrm{t}}$ egyenesének meredeksége - az eddig tapasztalthoz képest - nagyobb (kb. 51 fok) és negatív értéket vesz fel, míg a vasúti közlekedésben ennek ellentéte figyelhető meg, amelynek következtében hirtelen változás következik be, azaz az alábbi, közlekedésszervezési beavatkozások eszközölésével jelentősen növelhető a vasúti közlekedés versenyképessége. A zérus érték közelében az autóbusz és a vonat súlyszámai szinte azonosak, azaz a 0 érték közelében egyformán fontos a felhasználó számára az eljutási idő, illetve az eljutási költség, amelyekhez a kínálat is igazodik, versenyhelyzetet eredményezve. A fentiek értelmében egyrészről a szolgáltatási színvonal növelése javasolt mindkét közleke- dési mód esetében, hiszen a jelenlegi kínálat mellett közel azonos az utasok eljutási időre és eljutási költségre való érzékenysége, így bizonyos többletszolgáltatásokkal (pl. Wi-Fi, modern járművek stb.), vagy a jelentkező igények minél pontosabb megismerésével fejleszthető a szolgáltatás színvonala mindkét közlekedési mód fenntartása mellett. Amennyiben szükséges a súlyozott értékek közelítése, úgy a vasútvonalon megállóhely-optimalizáció hajtandó végre. Ide sorolható a Szeged-Békéscsaba vasútvonal, illetve a vele párhuzamosan futó autóbusz-vonalak, amelyek vonali szinten nagy lakosszámú településeket érintenek, hasonló (Szeged és Hódmezővásárhely relációt leszámítva) kínálati értékeket nyújtva. További jellemző, hogy a vasútállomások és az autóbuszállomások egy helyen és/vagy a belvároshoz közel helyezkednek el.

A 0 és 2 közötti szakasz nem várt eredményt mutat, ugyanis a felhasználók számára az eszközválasztás során nagyobb súllyal bír az eljutási idő értéke, amelyet az autóbusz képes hatékonyabban biztosítani. Ugyanakkor hangsúlyozandó, hogy a közlekedési módok közötti eltérés jóval kisebb értékkel bír, mint a -5 és -2 intervallumban $(\mathrm{kb} .0,4)$ és az egyenesek meredeksége ismét 40 fok körüli. 


\section{Közösségi közlekedés}

\section{5. ábra: Beavatkozási javaslatok a pontosított minőségimutató-értékek függvényében.}

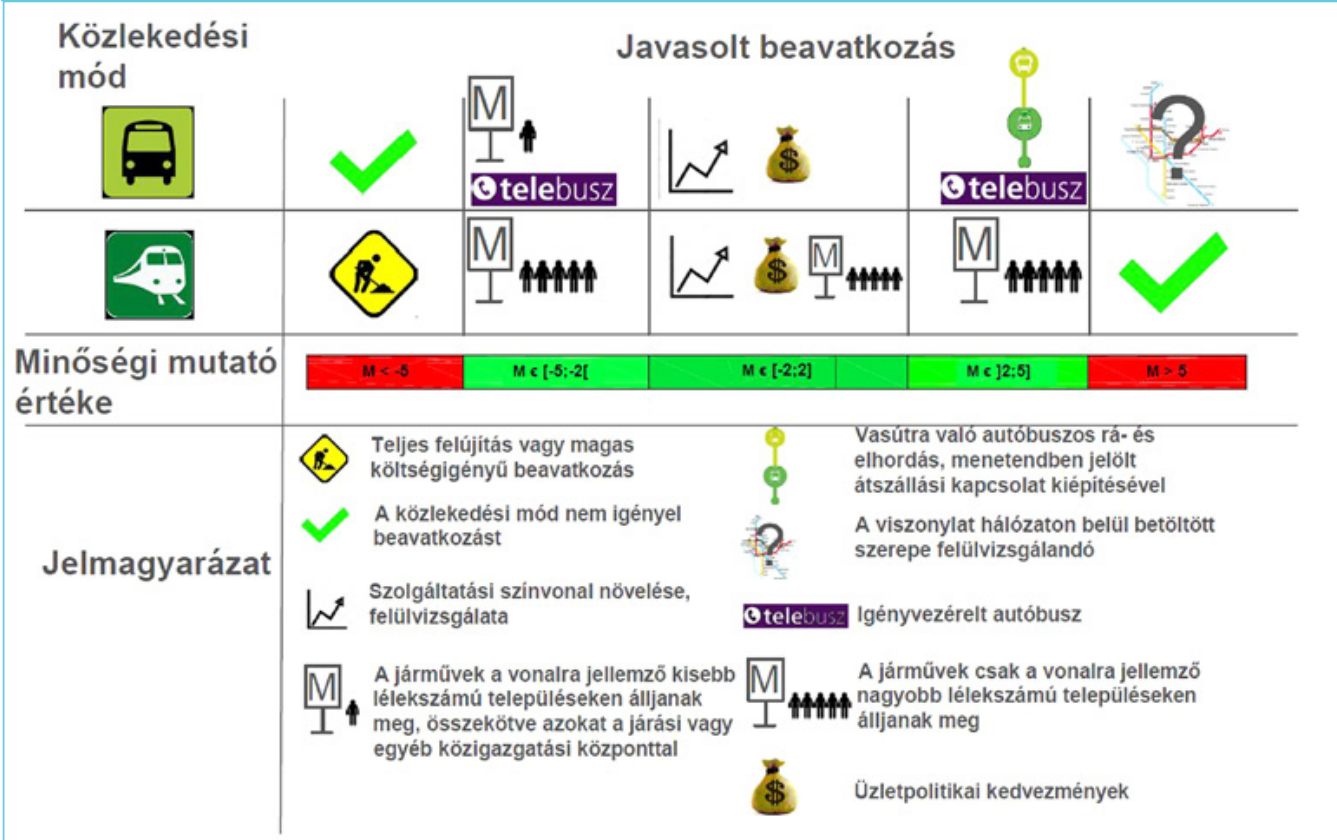

Beavatkozási javaslatként ajánlott - a kisebb mértékü eltérésre való tekintettel - a vasúti közlekedésben a megállóhely-optimalizáció végrehajtása az eljutásiidö-értékének csökkentése végett, valamint mindkét közösségi közlekedési mód megtartása mellett a szolgáltatási színvonal növelése az utazási igények térben és időben történő elosztásával az autóbuszos és vasúti közlekedés között (pl. csúcsidőben párhuzamos kínálat, csúcsidőn kívül vasúti menetrenddel összehangolt ráhordó autóbusz-járatok), illetve üzletpolitikai kedvezmények bevezetése (pl. kombinált bérlet stb.). Jellemzően azon párhuzamosan futó vasút-, illetve autóbusz-vonalak tartoznak ide, amelyek sürün lakott, nagy utasforgalmi igényeket generáló településeket kötnek össze a városok különböző pontjait feltárva.

Mivel látható, hogy a -2 és 0 , valamint a 0 és 2 közötti minőségimutató-érték intervallumokban az egyes egyenesek meredeksége eltérö, viszont a javasolt beavatkozások hasonlók, ezért utóbbi terén megbontásuk nem reális.
A 2 és 5 közötti intervallumban az autóbuszközlekedés által garantált eljutásiidö-értékek súlyszáma folyamatosan csökkenő tendenciát mutat, míg a vasúté növekedőt. Ez azt jelenti, hogy a közlekedési módok által kínált szolgáltatások ismét közelítenek a versenyhelyzethez, amelyet az egyenesek metszéspontja szimbolizál az 5-ös értékü minőségimutatóhozközel. A vasúti közlekedés - eljutási idő alapú - versenyhelyzetének növelése érdekében megállóhely-optimalizáció, illetve ezt követöen rá- és elhordó (helyi) autóbuszhálózat kialakítása szükséges, a kimaradt megállóhelyek igényvezérelt autóbusz-közlekedéssel történő kiszolgálása mellett.

Az 5 feletti minőségimutató-értékek esetében az eljutásiidő-értékek súlyszámát leíró egyenes az autóbusz-közlekedés terén folyamatosan csökken a határpontig (10,62 11), ahol konstans értéket vesz fel $(0,01)$, míg a vasúti közlekedést szimbolizáló egyenes folyamatosan nő szintén a határpontig, ahol eléri maximális értékét $(0,99)$, majd konstans lesz. Fontos kiemelni tehát, hogy a határpontnál nagyobb 


\section{Közösségi közlekedés}

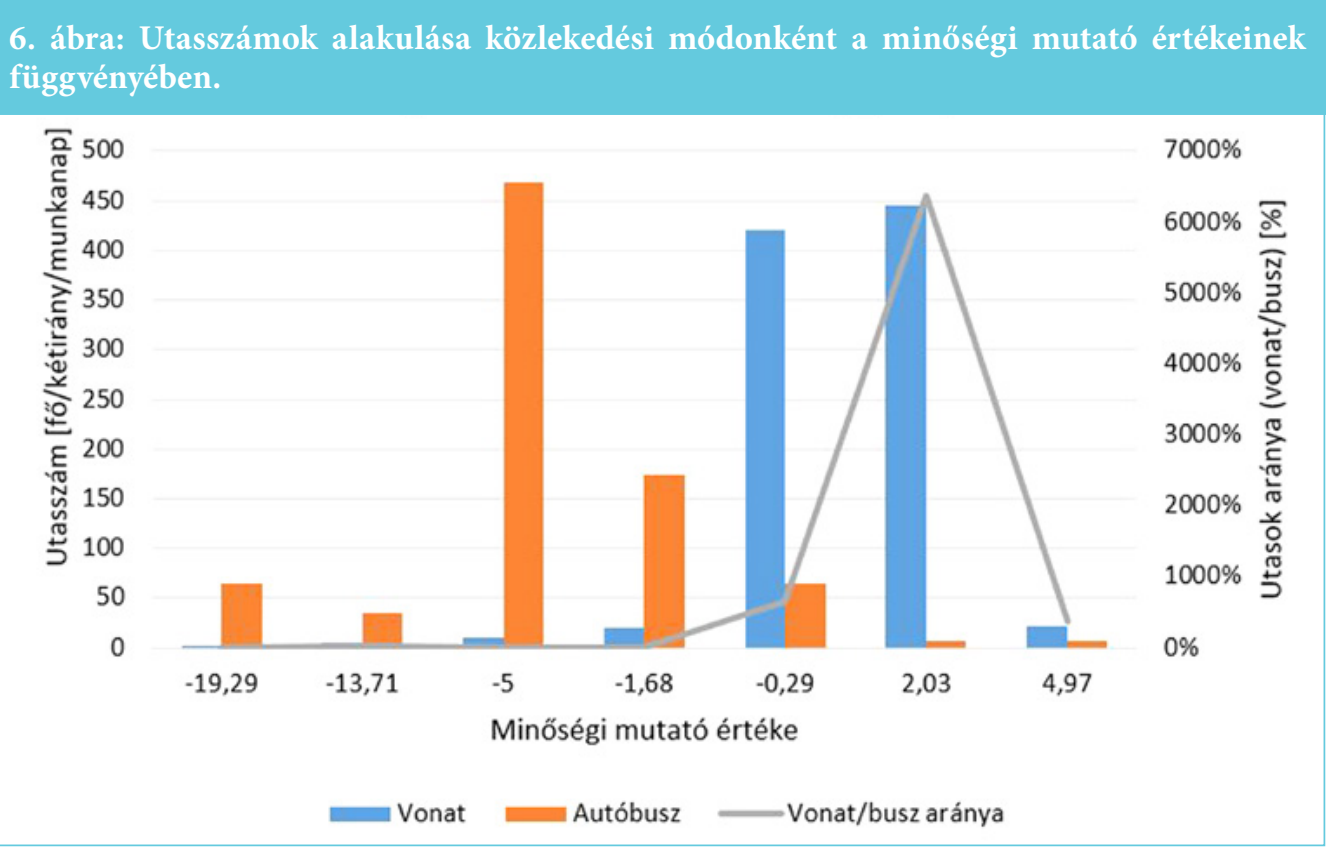

minőségimutató-értéket párhuzamos kínálat esetén, vonali szinten garantálni nem racionális, hiszen se a költség, se az eljutási idő eszközválasztásra gyakorolt hatásán érdemleges változtatás nem érhető el.

Az 5 és 11 közötti minőségimutató-értékek esetében tehát a vasúti közlekedést a felhasználók egyre nagyobb súllyal választják a kínált eljutásiidő-értékek miatt, míg az autóbuszközlekedést választók számára annak költsége jelenti a legfőbb vonzerőt. Ebből kifolyólag - a -5 alatti minőségimutató-értékekhez hasonlóan - nagyságrendi eltérések tapasztalhatók az utasszám területén a két közlekedési mód között, ezúttal a vasúti közlekedés javára. Ezek alapján a vasúti közlekedés nem igényel beavatkozást, míg az autóbuszvonal hálózaton belül betöltött szerepe felülvizsgálandó.

A fenti következtetések, meggondolások alapján a pontosított minőségimutató-értékek függvényében javasolt beavatkozásokat az 5 . ábra tartalmazza.

A korábbi kutatások során a Debrecen - Füzesabony párhuzamosan futó vasút- és autóbuszvonal - a fenti beavatkozási javaslatok, valamint egy finnországi példa alapján - minőségimutató-értékének növelése történt, így a jelenlegi kínálati paraméterek szerint számított 4,97-es érték 7,80-ra emelkedett. Ráillesztve ezt az értéket a 3. és 4 . ábrán foglaltakra elmondható, hogy a párhuzamos vonalak közötti versenyhelyzet megszünt, az eljutásiidő-értékek, mint súlytényezők tekintetében a vasúti közlekedés élvez elönyt, míg az autóbuszt annak költsége miatt választják az utasok.

Az elözőek és a 6. ábra alapján valószínüsíthető, hogy a beavatkozás utasszám-növekedést is fog okozni a kötöttpályás közlekedésben, hiszen a zérus minőségimutató-értéket követöen az elszállított utasok aránya megnő a vasúti közlekedési eszközökön, míg az alatt az autóbuszokat veszik igénybe a felhasználók.

Fontos megjegyezni, - amint ez a korábban végzett kérdőíves kutatásokból kiderül, hogy rövidebb távú (100 km alatti) helyközi, munkamotiváltságú utazások során a kedvező eljutásiidő-értékkel rendelkező közlekedési módot választják a felhasználók, ugyanis a válaszadók közel 80\%-a első preferencia-helyen jelölte meg az utazási időt. 


\section{KONKLÚZIÓ}

A magyarországi regionális - és távolsági - közlekedésben lévő párhuzamos autóbusz- és vasútvonalak aktuális és visszatérő problémát jelentenek, mivel a hazai és nemzetközi közlekedéspolitika a fenntartható közlekedés érdekében megköveteli, hogy a különböző közlekedési módok egymás kiegészítői legyenek. Ehhez elengedhetetlenül szükséges a párhuzamosan futó vonalak optimalizálása.

Jelen vizsgálat hipotézise a korábbi kutatások során meghatározott minőségimutató-értékek analitikus úton történő alátámasztása. A bizonyításhoz a vizsgált, Magyarország összes régióját lefedő regionális - azaz 100 kilométer alatti - és párhuzamosan futó autóbusz- és vasútvonal utasszám-adatai és a kínált eljutási idő- és eljutási költség-értékek kerültek értékelésre a logit-modell, mint matematikai módszer segítségével.

A fent említett eljárás alapján az eljutási időre és eljutási költségre vonatkozó súlyszámok kerültek meghatározásra mind az autóbusz-, mind pedig a vasúti közlekedést illetően. Az említett súlyszámok minőségimutató-értékekhez való hozzárendelésével leírhatóvá vált az egyes minőségre vonatkozó érték-intervallumokban az utasszámok alapján képzett felhasználói súlyértékekből adódó függvények meredeksége, amely jól szimbolizálja a közlekedési módok közötti versenyhelyzet jellegét.

Amennyiben a minőségimutató-értéke -5 alatti, úgy a költség- és időegyenesek kvázi konstansok és az autóbusz-közlekedést a felhasználók többségben a kínált kedvező eljutási idő miatt választják, amelyet az időre, mint súlytényezőre vonatkozó egyenes magas értéke mutat. Ebben az esetben - mivel konstans számokról van szó - a vasúti közlekedés versenyképességének növelése pusztán közlekedésszervezési eszközökkel nem lehetséges.

A -5 és - 1 közötti minőségre vonatkozó értékek között már körülbelül 45 fokos egyenese- ket mutatnak az egyes súlyértékek, amelynek alapján a vasúti közlekedés versenyképessége megállóhely-optimalizációval javítható, hiszen a - 1 és +1 közötti intervallumban már az egyes egyenesek előjelet váltanak és meredeken közelítenek a versenyhelyzethez, amelyet végül a zérus pont környékén érnek el. Mivel az egyenesek meredekségében az előjelváltás a -2 értékhez közelebb történik, ezért az előző kutatások eredményeihez képest a minőségimutató-határértékét -1 értékről -2 értékre szükséges módosítani.

Szintén elöjelváltás történik a +2 értékhez közel. Az addig az eljutási idő terén növekvő tendenciát mutató - de a versenyhelyzettől kevésbé távolodó - autóbuszra vonatkoztatott súlyszámok függvényének meredeksége negatív értéket vesz fel, a vasúté pedig ennek fordítottját mutatja. Ezért itt is pontosítani szükséges az eddigi +1 értéken lévő minőségimutató-határértéket +2 értékre.

A +5 értéket követően a versenyhelyzet teljesen megszűnik, a vasúti és autóbuszos közlekedés időegyenesei a +10 ,62 értékig folyamatosan távolodnak egymástól, ahol elérik a legnagyobb értékét $(0,99$, illetve 0,01$)$, így az utóbb említett érték jelenti a határpontot. Innentől ismét konstansként viselkedik mindkét függvény, így e határpont feletti minőségimutató-értéket nem racionális elérni, hiszen az eszközválasztást befolyásoló paraméterek súlya változatlan.

Fontos - korábbi, gyakorlati kutatásokból adódó - összefüggés, hogy a felhasználók döntő többsége (kb. $80 \%$ ) számára az utazással töltött idő a legfontosabb az eszközválasztás során. Így elmondható, hogy az egyes minőségimutató-intervallumokat illetően, az időegyenesen történő minél magasabb érték elérése érdekében - a közlekedéspolitikai szempontok figyelembevétele mellett - a javasolt beavatkozások helytállók.

Jelen vizsgálat során, analitikus módon is igazolásra kerültek a korábbi, regionális és párhuzamos közösségi közlekedés optimalizálására törekvő kutatások során elért eredmények. Elmondható, hogy a közforgalmú közlekedésre vonatkozó különböző kínálati 
paraméterek és demográfiai adatok alapján matematikai módon képzett, minőségre vonatkozó mutatószámmal értékelhetők az adott párhuzamos vonalak, amelyek alapján beavatkozások javasolhatók. Mindezeket az utasforgalmi felmérésekből származó adatok, az eljutási idő- és az eljutási költség-értékek felhasználásával, logit-modell segítségével meghatározott súlytényezők is alátámasztják. Továbbá megjegyzendő, hogy a kapott eredmények összhangban vannak az eddig végzett, nem elméleti - kérdőíves kikérdezés alkalmazásával végzett - kutatásokból kapott eredményekkel is.

A hazai regionális közlekedésben lévő párhuzamosságok optimalizálása - mint a 2016 szeptembere óta tartó kutatásunk fö célja - a kidolgozott módszertan és az abban javasolt beavatkozások alapján lehetséges. A kutatás tartalmának továbbfejlesztésével - különösképp az egyéni közlekedést is bevonva -, az esetleges hibák kiküszöbölésével a vizsgálat által adott eredmények tovább finomíthatók. Természetesen az országos szintű optimalizálás komplex vizsgálatokat igényel, amelynek egy szelete került bemutatásra.

\section{Az OCF-2016 projekt keretein belül megva- lósult utasforgalmi mátrixokra vonatkozó adatszolgáltatásért szíves köszönetünket fejezzük ki Miksztai Péternek, a KTI Köz- lekedéstudományi Intézet Nonprofit Kft. munkatársának.}

\section{FELHASZNÁLT IRODALOM}

[1] Ács Balázs: A távolsági autóbusz-hálózat múltja, jelene, jövője. KTI évkönyv, 2007.;

[2] Ács Balázs: Piacnyitás és üzleti alapú személyszállítás lehetősége Magyarországon. „Új megoldások a közösségi közlekedésben, Modern Városok Program, Területfejlesztés, Elektronikus jegyrendszer" címü KTE konferencia, Harkány, 2017. november 10.;

[3] Albert Gábor - Tóth Árpád: A párhuzamosság, helyettesíthetőség számszerüsítése a közforgalmú közlekedésben. Közlekedéstudományi Szemle, 2008. November.;
[4] Farkas Dávid, Hagymási Gergely, Nagy Balázs: A helyközi közösségi közlekedés jelenlegi helyzetének ismertetése és hazai szervezésének lehetõségei. Vezetéstudomány, XLI. évfolyam, 2010. 5. szám.;

[5] Fenghua Zhu, Songhang Chen, Yisheng Lv, Peijun Ye, Gang Xiong, Xisong Dong: Parallel public transport system and its application in the evacuation of largescale activities. Intelligent Transportation Systems (ITSC), 2012 15th International IEEE Conference,; DOI: http://doi.org/ dbh5

[6] Hajdú. L., „A logisztikus függvény és a logisztikus eloszlás," Statisztikai szemle, \%1. kötet82., \%1. szám10-11., pp. 9911011., [2004].

[7] Kövesné dr. Gilicze Éve, dr. Debreczeni Gábor, dr. Csiszár Csaba: Személyközlekedés. Digitális tananyag, 2014. November.

[8] KTI Közlekedéstudományi Intézet Nonprofit Kft. Közlekedésfejlesztési Kutatóközpont: Országos célforgalmi felvétel és mátrixok kidolgozása (OCF-2016), TEN-T elemzések. 2017. november 30.

[9] Lakatos A., dr. Mándoki P.: A magyarországi regionális vasúti és autóbuszos személyszállítás párhuzamosságának többszempontú vizsgálat alapján történő összehasonlítása. XII. IFFK 2018 Konferencia, Paper 26. ISBN Online: 978-963-888753-5, CD: ISBN 978-963-88875-2-8. p. 371.

[10] Lakatos A., dr. Mándoki Péter: Felhasználói eszközválasztás vizsgálata a távolsági, párhuzamos közösségi közlekedésben. Közlekedéstudományi Konferencia Győr 2019. ISBN: 978-963-8121-86-8. Egyéb konferenciaközlemény (konferenciaközlemény). p. 1. cikk azonosító: 36

[11] Lakatos András, dr. Mándoki Péter: A magyarországi párhuzamos távolsági autóbuszos és vasúti közlekedés összehasonlítása felhasználói oldalon jelentkező minőségi elvárások alapján. XI. IFFK 2017. Konferencia, Oldal 249-254., ISBN Online: ISBN 978-963-88875-3-5, CD: ISBN 978-963-88875-2-8

[12] Lakatos András: A budapesti villamosközlekedés versenyképességének fejlesztése. 2014. 
[13] M. L. Buis, "Logistic regression: When can we do what we think we can do?," http://www.maartenbuis.nl/wp/odds_ ratio_3.1.pdf, 29 May [2016].

[14] P. Allison, „Comparing logit and probit coefficients across groups," Sociological Methods \& Research, 28. kötet., 1. szám, pp. 186-208., [1999].

[15] Változik a H6-os, a H8-as és a H9-es HÉV menetrendje - több vonat, jobb csatlakozások. MÂV-HÉV Zrt.. Megtekintetés:
2017. június 15. https://web.archive.org/ web/20170807153444/http://bhevzrt.hu/ hu/hirek/valtozik-a-h6-os-a-h8-as-esa-h9-es-hev-menetrendje-2017-06-14-tobb-vonat-jobb-csatlakozasok

[16] VR to close nearly 30 train stations, some routes. Megtekintés: 2017. 12. 08. https://yle.fi/uutiset/osasto/news/vr_to_ close_nearly_30_train_stations_some_ routes $/ 8307702$.

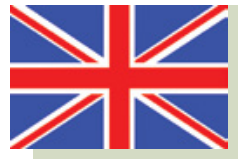

An analytical study of the parallelism of Hungarian regional rail and bus passenger transport using the logit model

The parallelism of regional bus and rail passenger transport in Hungary is a relevant problem, since sustainable and efficient transport requires that the subsectors are complementary within certain limits. In all regions of Hungary, bus and rail public transport lines can be found in parallel, which may result in competition between the two sub-sectors. This means that the complementary role is not fulfilled. In order to address this problem, it is necessary to optimize the current parallel public transport options.

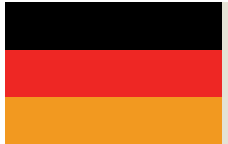

Eine analytische Studie zur Parallelität des ungarischen regionalen Schienen- und Buspersonenverkehrs anhand des logit-Modells

Die Parallelität des regionalen Bus- und Schienenpersonenverkehrs in Ungarn ist ein relevantes Problem, da ein nachhaltiger und effizienter Verkehr erfordert, dass sich die Teilsektoren in bestimmten Grenzen ergänzen. In allen Regionen Ungarns gibt es parallele Linien des öffentlichen Bus- und Schienenverkehrs, was zu einem Wettbewerb zwischen den beiden Teilsektoren führen kann. Dies bedeutet, dass die Komplementärrolle nicht erfüllt ist. Um dieses Problem anzugehen, müssen die derzeitigen Optionen für den parallelen öffentlichen Verkehr optimiert werden.

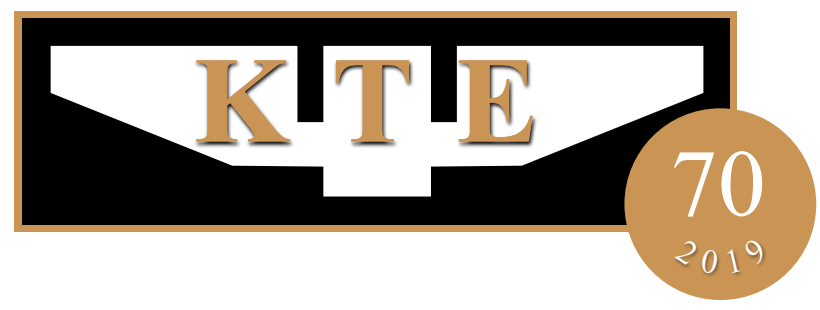

